\title{
Correction to: Educational Situation of Portuguese Ciganos: Social Changes versus Social Continuities
}

\author{
Maria Manuela Mendes and Olga Magano
}

\section{Correction to: \\ Chapter 2 in: M. M. Mendes et al. (eds.), Social and Economic Vulnerability of Roma People, https://doi.org/10.1007/978-3-030-52588-0_2}

The original version of the Chapter was inadvertently published without incorporating the author's proof corrections. The chapter has now been corrected and approved by the author.

As per editor's request, Chapter title has also been changed from 'Ciganos, Families and Social Policies in Portugal: What Has Changed in the Ciganos Attitude Towards School?' to 'Educational Situation of Portuguese Ciganos: Social Changes versus Social Continuities'.

Open Access This chapter is licensed under the terms of the Creative Commons Attribution 4.0 International License (http://creativecommons.org/licenses/by/4.0/), which permits use, sharing, adaptation, distribution and reproduction in any medium or format, as long as you give appropriate credit to the original author(s) and the source, provide a link to the Creative Commons licence and indicate if changes were made.

The images or other third party material in this chapter are included in the chapter's Creative Commons licence, unless indicated otherwise in a credit line to the material. If material is not included in the chapter's Creative Commons licence and your intended use is not permitted by statutory regulation or exceeds the permitted use, you will need to obtain permission directly from the copyright holder.

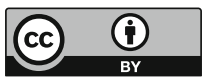

The updated online version of this chapter can be found at https://doi.org/10.1007/978-3-030-52588-0_2 